\title{
Efflux of Dopamine from the Synaptic Cleft in the Nucleus Accumbens of the Rat Brain
}

\author{
Paul A. Garris, Edward L. Ciolkowski, Paolo Pastore, and R. Mark Wightman \\ Department of Chemistry and Curriculum in Neurobiology, University of North Carolina, Chapel Hill, North Carolina \\ 27599-2390
}

\begin{abstract}
Synaptic release of dopamine in the nucleus accumbens of the intact rat brain elicited by a single electrical impulse applied to ascending dopaminergic fibers results in extracellular concentrations sufficient to bind the known dopamine receptors. The dopamine concentration observed after four rapid, sequential pulses is exactly four times greater and is unaffected by pharmacological antagonism of dopamine uptake and receptor sites at supramaximal concentrations. Thus, dopamine efflux from the synaptic cleft is not restricted by binding to intrasynaptic proteins on the time scale of the measurements $(50-100 \mathrm{msec})$. The extracellular concentration, as a result of a single stimulus pulse, is $\mathbf{0 . 2 5}$ $\mu \mathrm{M}$ and is rapidly removed by extrasynaptic uptake. This maximal, transient concentration of dopamine is 60 times higher than steady-state concentrations reported previously using dialysis techniques, illustrating that dopamine extracellular concentrations are spatially and temporally heterogenous. In contrast to ACh transmission at the neuromuscular junction, the dopamine synapse in the telencephalon is designed for the effective efflux of dopamine from the synaptic cleft to the extrasynaptic compartment during neurotransmission.
\end{abstract}

[Key words: dopamine, dopamine release and uptake, dopamine receptors, nucleus accumbens, synaptic and extrasynaptic neurotransmission, fast-scan cyclic voltammetry, rat]

Fluctuations in the concentration of neurotransmitters that accompany a neuronal impulse have not been temporally or spatially resolved in the intact brain. For this reason, current views of chemical neurotransmission in the CNS are based on observations for acetylcholine ( $\mathrm{ACh}$ ) at peripheral synapses (Cooper et al., 1991). $\Lambda t$ the neuromuscular junction, $\Lambda \mathrm{Ch}$ is released into the synaptic cleft, diffuses, activates receptors, and is hydrolyzed by acetylcholinesterase (AChE) (Eccles and Jaeger, 1958; Katz and Miledi, 1973; Wathey et al., 1979; Bartol et al., 1991). The diffusion of $\mathrm{ACh}$ in the junctional gap is retarded by rapid binding to receptor sites, especially in the absence of the esterase. This process, termed "buffered diffusion" (Katz and Miledi, 1973), in addition to the presence of postsynaptic invaginations,

\footnotetext{
Received Nov. 29, 1993; revised Mar. 18, 1994; accepted Apr. 6, 1994.

This research was supported by NIH (NS-15841) and NSF (IBN-92-22349). We gratefully acknowledge helpful discussions with $\mathrm{H}$. Lester.

Correspondence should be addressed to Professor R. Mark Wightman, Department of Chemistry and Curriculum in Neurobiology, CB\# 3290, Venable Hall, The University of North Carolina at Chapel Hill, Chapel Hill, NC 27599-3290.

Copyright (c) 1994 Society for Neuroscience $0270-6474 / 94 / 146084-10 \$ 05.00 / 0$
}

increases the probability of degradation by the csterase (Magleby and Terrar, 1975; Armstrong and Lester, 1979; Wathey et al., 1979; Land et al., 1980, 1981, 1984; Bartol, 1991). Thus, chemical communication at the neuromuscular junction is restricted spatially to the length of the synaptic cleft (about $1 \mu \mathrm{m}$ ).

This article describes an investigation of chemical transmission by central dopamine neurons to test whether these same concepts apply in the brain. Dopamine neurons play an important role in normal CNS function (Le Moal and Simon, 1990), and there is evidence to suggest that dopamine neurotransmission is regionally distinct (Bannon and Roth, 1983; Glowinski et al., 1984; Kilts et al., 1988; Garris and Wightman, 1994). A synaptic mode of transmission is suggested by anatomical features indicative of dopamine synapses in all telencephalic dopamine terminal fields examined in the rat (Doucet et al., 1986; Descarries et al., 1987). In the densely dopamineinnervated caudate-putamen and nuclcus accumbens of the striatum, dopamine neurons form en passant, symmetric synapses on dendritic spines and shafts of medium spiny neurons (Freund et al., 1984; Voorn et al., 1986; Gerfen, 1988). These synapses are spaced $4 \mu \mathrm{m}$ apart on average, and are typically characterized by two parallel, thickened membranes, $300 \mathrm{~nm}$ in length, which are separated by a cleft of $15 \mathrm{~nm}$ (Pickel et al., 1981; Groves et al., 1994). Synaptic vesicles are densely packed in the presynaptic regions but are sparse in the intervening axonal segments. Furthermore, high-affinity $\left(K_{\mathrm{m}}=0.16 \mu \mathrm{M}\right)$ dopamine uptake (Near et al., 1988) is to proposed terminate the effects of dopamine in the synaptic cleft (Horn, 1990; Giros and Caron, 1993) and to maintain the low (nanomolar), steady-state concentrations of extracellular dopamine, as measured by in vivo microdialysis, in the striatum (Parsons and Justice, 1992). Thus, the dopamine uptake transporter has been likened to play a role similar to $\Lambda \mathrm{ChE}$ in the neuromuscular junction, which is to limit the efflux of dopamine from the synaptic cleft to the extrasynaptic compartment during neurotransmission.

On the other hand, neurochemical, physiological, and behavioral experiments have implicated a role for extrasynaptic communication by dopamine (Johnson et al., 1986; Schenk and Bunney, 1987; Fuxe and Agnati, 1991; Gonon et al., 1991). In Parkinson's disease, for example, reduced dopamine uptake, due to the loss of dopamine neurons, is thought to enable released dopamine to diffuse farther from the remaining dopamine synapses and into denervated regions (Zigmond et al., 1990). This hypothesis is predicated on the capacity for functionally significant concentrations of dopamine to leave the synaptic cleft and reach distal sites. In addition, iontophoretic dopamine and endogenous dopamine elicited by long-duration electrical stimulation have different electrophysiological effects compared to 


\section{EXPERIMENTAL}

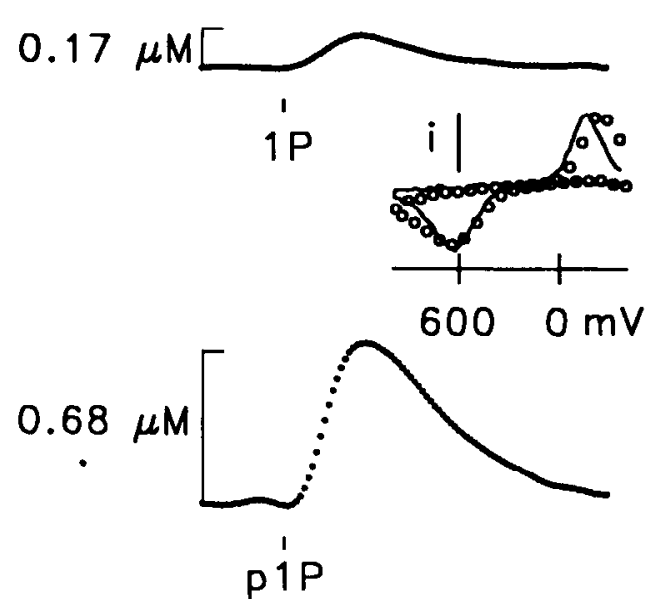

DECONVOLUTED

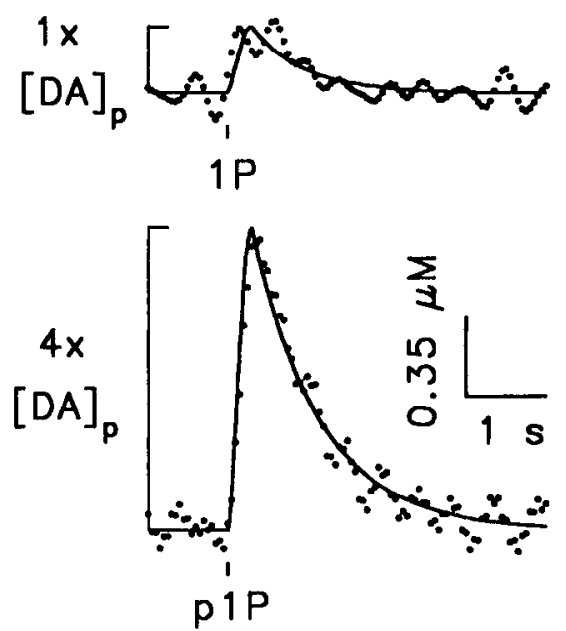

Figure 1. Left, Individual curves collected in the core of the nucleus accumbens after nomifensine administration ( $25 \mathrm{mg} / \mathrm{kg})$ and elicited by $1 \mathrm{P}$ and p1P stimulation. Scans were collected every $50 \mathrm{msec}($ dots $)$ and the time of stimulation is shown by the vertical line. Curves are the average of 40 measurements for $\mathrm{p} 1 \mathrm{P}$ and 80 measurements for $1 \mathrm{P}$ stimulation, and collected in the same location. Inset, Background-subtracted cyclic voltammogram collected in vivo from the $1 \mathrm{P}$ data shown (solid line) and in vitro from dopaminc (open circles). Current calibration, $0.05 \mathrm{nA}$. Right, Temporal responses were deconvolved to account for the time delay $(\sim 400 \mathrm{msec})$ caused by the Nafion coating the working electrode (dots). The simulation (solid line) used the following parameters: [DA $]_{p}=0.35 \mu \mathrm{M}, K_{\mathrm{m}}=4.98 \mu \mathrm{M}, V_{\max }=6.3 \mu \mathrm{M} / \mathrm{sec}$. Data and model were digitally filtered using a cutoff frequency of $2 \mathrm{~Hz}$ and an apodization slope of $1 \mathrm{sec}$.

endogenous dopamine elicited by short-duration stimulation (Williams and Millar, 1990, 1991), which could be interpreted to suggest that dopamine is acting on spatially distinct, extracellular compartments.

The study of dopamine neurotransmission is advanced by the capability to monitor directly dopamine electrochemically. In this work, extracellular measurements of dopamine were obtained in the core of the nucleus accumbens of the anesthetized rat in vivo using fast-scan voltammetry with sensors that have microscopic $(15 \mu \mathrm{m})$ tips. This technique allows the determination of extracellular dopamine levels in the intact brain with unprecedented spatial and temporal resolution (Adams, 1990). Prior work with voltammetry has established that evoked impulse flow in the medial forebrain bundle, using trains of electrical stimulation, elicits an increase of extracellular dopamine in the striatum (Millar et al. 1985; Kuhr et al., 1986). However, it would be desirable to evaluate the likelihood that dopamine leaves the synaptic cleft after a single presynaptic impulse (Valenta et al., 1988; Palij et al., 1990; Limberger et al., 1991; Kennedy et al., 1992). Synaptic efflux during stimulus trains could be enhanced because of saturation of uptake and receptor binding sites within the synaptic cleft by previously released dopamine. In the following experiments, we examine dopamine release evoked by one stimulus pulse (1P) and four stimulus pulses delivered within $30 \mathrm{msec}$. The latter "pseudo-one-pulse" (p1P) should provide insufficient time for dopamine receptors and uptake transporters to function between pulses, although binding to these sites is not precluded (Mayer et al., 1988; Singer, 1988).

\section{Materials and Methods}

Surgical procedures. Male Sprague-Dawley rats (350-500 gm; Charles River Laboratories, Wilmington, MA) were anesthetized with urethane $(1.5 \mathrm{~g} / \mathrm{kg})$ administered intraperitoneally, placed in a stereotaxic frame, and maintained at $37^{\circ} \mathrm{C}$. Carbon-fiber working electrodes were lowered into the nucleus accumbens $(+1.2 \mathrm{~mm} \mathrm{AP},+1.4 \mathrm{~mm} \mathrm{ML},-6.8 \mathrm{~mm}$ DV, referenced to bregma and dura according to the atlas of Paxinos and Watson, 1986) and a twisted bipolar stimulating electrode (Plastics One, Roanoke, VA) was lowered to the medial forebrain bundle $(-4.6$ $\mathrm{mm} \mathrm{AP},+1.4 \mathrm{~mm} \mathrm{ML},-9.0 \mathrm{~mm} \mathrm{DV}$ ) as previously described (Garris et al., 1993).

Electrical stimulation. Stimulus pulses were biphasic, $\pm 350 \mu \mathrm{A}$ in amplitude and $4 \mathrm{msec}$ wide, and optically isolated from the electrochemical instrumentation (NL 800, Neurolog, Medical Systems Corp., Great Neck, NY). Stimulus trains (120 pulses) at $20 \mathrm{~Hz}$ and $60 \mathrm{~Hz}$ were computer generated. $1 \mathrm{P}$ and $\mathrm{p} 1 \mathrm{P}$ were generated by a computer-triggered Grass S88 stimulator (Grass Instruments, Quincy, MA).

Electrochemistry. Carbon-fiber microelectrodes were prepared as described previously (Kawagoe et al., 1993), polished at a $25^{\circ}$ angle, and coated with Nafion $(2.5 \% \mathrm{w} / \mathrm{v})$ to restrict chemical interferences (Baur et al., 1988). Fast-scan cyclic voltammetry employed a potentiostat (EI400 , Ensman Instrumentation, Bloomington, IN) with provision for two working electrodes and the applied potential consisted of a -400 to $1000 \mathrm{mV}, 300 \mathrm{~V} / \mathrm{sec}$ triangle wave repeated at 50 or $100 \mathrm{msec}$ intervals. The output was computer digitized, and the dopamine signal was monitored over the peak oxidation potential for dopamine $(600$ $\mathrm{mV}$ ). The current was converted to concentration based on calibration of the working electrode postexperiment with dopamine in vitro (Wiedemann et al., 1991). A sodium-saturated calomel electrode was used as the reference electrode in all experiments and placed in electrical contact with dura through a salt bridge.

Data analysis. The measured time courses of extracellular dopamine were best fit to a previously described set of equations (Wightman et al., 1988; Wightman and Zimmerman, 1990). The equations assume that (1) a fixed concentration of dopamine, $[\mathrm{DA}]_{p}$, appears in the extracellular fluid with each stimulus pulse, and (2) cellular uptake, which is described by Michaelis-Menten kinetics and characterized by a $K_{\mathrm{m}}$ and $V_{\max }$, can occur between each pulse and in the time interval after the stimulation. Thus, the rate of appearance of dopamine in the extrasynaptic space is described by

$$
\frac{d[\mathrm{DA}]}{d t}=f \cdot[\mathrm{DA}]_{p}-\frac{V_{\max }}{\frac{K_{\mathrm{m}}}{[\mathrm{DA}]}+1},
$$

where [DA] is the extrasynaptic concentration of dopamine and $f$ is the stimulation frequency. The values for $V_{\max }$ and $K_{\mathrm{m}}$ were obtained from the analysis of the curves evoked by 20 and $60 \mathrm{~Hz}$ stimulus trains using a simplex minimization algorithm; the uptake parameters were then used to obtain $[\mathrm{DA}]_{p}$ values from the $1 \mathrm{P}$ and p1P data using Brent's method (Press et al., 1989). Distortion of the temporal response by the Nafion film on the electrode was quantitated by postcalibration and 
Figure 2. Individual curves elicited by p1P or a $6 \mathrm{sec}$ train of $20 \mathrm{~Hz}$ stimulation before and after nomifensine $(25 \mathrm{mg} /$ $\mathrm{kg})$. Curves are the average of 40 measurements for $\mathrm{plP}$ and one to three measurements for $20 \mathrm{~Hz}$ stimulation, and were collected in the same location. Graph, Average values for [DA $]_{p}$ before $(C O N)$ and after nomifensine $(N O M)$ given as the mean \pm SEM $(n=5-7$ rats). See Materials and Methods for details of modeling.

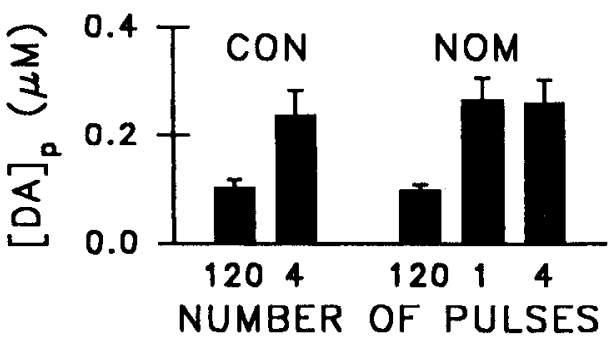

CONTROL

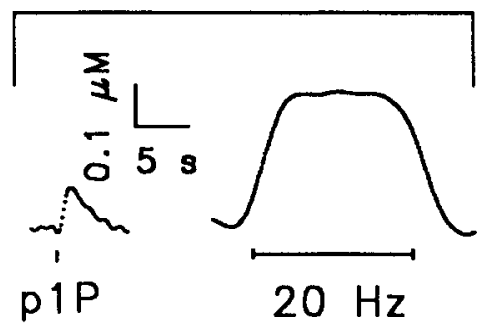

NOMIFENSINE

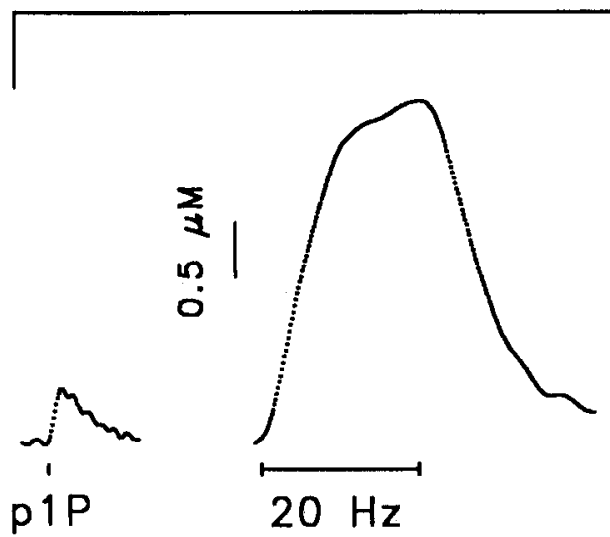

used to convolve the neurochemical model (Kawagoe, et. al, 1992) before comparison with the data.

Reagents and drugs. Drugs were administered intraperitoneally in physiological saline (150 mm sodium chloride). Nomifensine maleate $(25 \mathrm{mg} / \mathrm{kg}$ ) was a generous gift from Hoechst Roussel Pharmaceuticals (Somerville, NJ), and SCH-23390 hydrochloride was oblained from Research Biochemicals Incorporated (Natick, MA). Sulpiride, L-dopa, urethane, and dopamine (for postcalibration) were acquired from Sigma (St. Louis, MO). All solutions were prepared with doubly distilled water.

\section{Results}

\section{Comparison of one and four impulses on dopamine release}

To slow the rate of removal of dopamine from the extracellular space by cellular uptake, rats were pretreated with the dopamine uptake inhibitor nomifensine $(25 \mathrm{mg} / \mathrm{kg})$ and efflux elicited by a single stimulus pulse was measured in the extracellular fluid of the core of the nucleus accumbens. The dopamine concentration exhibits a transient increase as a result of the stimulation (Fig. 1, left). Under the same conditions, four stimulus pulses delivered within $30 \mathrm{msec}$ elicit a concentration increase that is exactly four times that elicited by one pulse. Deconvolved responses for $1 \mathrm{P}$ and $\mathrm{pl} \mathrm{P}$ are identical (Fig. 1, right); the latter can be approximated by scaling up the former by a factor of 4 . Deconvolution allows extrapolation of the dopamine concentration immediately after the stimulation, which for a single pulse is $[\mathrm{DA}]_{p}$ and $250 \mathrm{~nm}$ on average (Fig. 2, graph).

\section{Effects of uptake inhibition of dopamine release}

The amplitude of the transient extracellular increase in dopamine concentration evoked by $\mathrm{p} 1 \mathrm{P}$ was not altered by the absence of nomifensine (Fig. 2). In contrast, the efficacy of uptake inhibition is demonstrated by the reduced clearance rate of dopamine evoked by $\mathrm{p} 1 \mathrm{P}$ and dramatic differences in dopamine levels during $20 \mathrm{~Hz}$ stimulations before and after nomifensine. The marked increase in extracellular dopamine during stimulus trains after nomifensine administration is not due to an increase in release (Fig. 2, graph; May and Wightman, 1989), but is best modeled by a 15 -fold elevation of $K_{\mathrm{m}}(0.16$ to $2.42 \pm 0.56 \mu \mathrm{M}$, mean $\pm \mathrm{SEM} ; n=5$ ). The result is in agreement with the proposed effects of nomifensine as a competitive dopamine uptake inhibitor (Wightman and Zimmerman, 1990). Dopamine uptake still occurs in the presence of nomifensine (see Fig. 2) because the high value of $V_{\max }$ in the nucleus accumbens is unaltered and dopamine competes with the drug for the uptake binding sites.

\section{Effects of receptor antagonists on dopamine release}

Like nomifensine, neither the $\mathrm{D}_{1}$ receptor antagonist SCH 23390 $(0.1 \mathrm{mg} / \mathrm{kg})$ nor the $\mathrm{D}_{2}$ receptor antagonist sulpiride $(100 \mathrm{mg} /$ $\mathrm{kg}$ ) increased extracellular dopamine levels evoked by p1P (Fig. $3 A$ ). In contrast, sulpiride markedly increases dopamine efflux during a $20 \mathrm{~Hz}$ stimulation (Fig. $3 B$ ). The only treatment found to alter dopamine efflux evoked by p1P is $\mathrm{L}$-dopa $(250 \mathrm{mg} / \mathrm{kg})$, which acts intracellularly to increase dopamine stores (May et al., 1988). Average values for the maximum dopamine concentration elicited by p1P for control, sulpiride, SCH 23390, and $\mathrm{L}$-dopa were $184 \pm 22,191 \pm 38,193 \pm 64$, and $370 \pm 79 \mathrm{nM}$, respectively. The increase caused by $\mathbf{L}$-dopa was significant ( $p$ $<0.05, t$ test). Sulpiride caused a significant $(p<0.001)$ increase in the maximum dopamine concentration elicited by $20 \mathrm{~Hz}$ stimulation, from $0.527 \pm 0.069$ to $3.05 \pm 0.64 \mu \mathrm{M}$. SCH 23390 had no effect on extracellular dopamine levels elicited by trains (data not shown). Data are mean \pm SEM from at least four measurements.

\section{Failure rate of dopamine release during electrical stimulation}

Data shown in Figures 1-3 are the average results from repetitive 1P stimulations at single locations in the core of the nucleus accumbens. Examination of individual responses allows the determination of a failure rate for the impulses to evoke the efflux of dopamine from the synaptic cleft. Figure 4 shows 40 individual concentration curves elicited by $1 \mathrm{P}$ after administration of nomifensine $(25 \mathrm{mg} / \mathrm{kg})$. In total, we have examined $40 \mathrm{ad}-$ ditional curves collected in another rat and have found no evidence for failure of dopamine release. Thus, we estimate that the failure rate for dopamine release with this experimental paradigm is less than $1 / 80$ or $1.2 \%$.

\section{Discussion}

To obtain a complete understanding of dopamine neurotransmission, one would like to probe directly the spatial and tem- 
poral concentration changes that occur from the site of release to the interactions with a receptor (Ewing et al., 1992). Although this is not currently possible with any method, voltammetry as applied here provides temporally resolved information concerning the concentration of dopamine in the extrasynaptic compartment of extracellular fluid that is released from sites immediately adjacent to the sensor tip. Thus, the maximal dopamine concentration that appears at the sensor tip as a result of a single stimulus pulse reflects the initial release event, diffusion from the synaptic cleft, interaction with macromolecules en route to the extrasynaptic compartment, and removal from extracellular fluid by uptake (enzymatic degradation of dopamine occurs at a much slower rate than the present time scales; Michael et al., 1985). The major finding of this work is that binding to receptor and uptake sites does not appreciably alter the efflux of dopamine from the synaptic cleft to the extrasynaptic compartment. This has two important ramifications: (1) it appears that the dopamine synapse is designed for effective transmitter efflux from the cleft, which allows the possibility of extrasynaptic transmission, and (2) the measured extracellular concentration from these experiments can be used to extrapolate to the events that occur in the synaptic cleft at the instant of exocytosis.

\section{Factors regulating dopamine efflux from the synaptic cleft}

The design of the experiments was to test the hypothesis that dopamine neurotransmission in the CNS is regulated hy similar factors as those that have been established for cholinergic transmission at the neuromuscular junction. Given this analogy, a plausible scheme for dopaminergic transmission is that release of a packet of dopamine molecules into the synaptic cleft would be followed by diffusion to a receptor site. Receptor binding not only activates pre- and postsynaptic events, but also would slow the rate of mass transport out of the synaptic cleft by the process of buffered diffusion. The slowed rate of mass transport would provide time for the dopamine uptake transporter to remove dopamine and thus restrict dopamine efflux from the synaptic cleft. The first test was to compare dopamine release induced by a single pulse with that induced by four pulses delivered in rapid succession. Dopamine efflux induced by plP was found to be cxactly four times grcater than that induced by $1 \mathrm{P}$. Since the maximal dopamine concentration in the extracellular fluid evoked per stimulus pulse is identical with the two stimulations, this strongly implies that binding to either receptor or uptake sites does not restrict dopamine efflux from the synaptic cleft.

Next, the effects of the dopamine receptor and uptake transporter on dopamine efflux were tested with well-characterized pharmacological agents. The dopamine uptake inhibitor nomifensine did not affect dopamine release evoked by p1P. In contrast, uptake is very effective at lowering dopamine extracellular concentrations, as evidenced by the increased dopamine accumulation in the extracellular fluid during stimulus trains after uptake inhibition. In an attempt to probe buffered diffusion, the effects of dopamine receptor antagonists were investigated. Neither sulpiride nor SCH 23390 affected maximal extracellular dopamine levels evoked by p1 P. In contrast, sulpiride incrcased relcase during longer stimulus trains. This well-documented effect is due to blockade of autoreceptors receptors that normally inhibit release when activated by dopamine (Starke, 1989). The short duration of the p1P ( $30 \mathrm{msec})$ gives insufficient time for dopamine autoreceptors to function between pulses (Mayer et al., 1988; Singer, 1988). Taken together, these results indicate that dopamine neurotransmission in the CNS and ACh

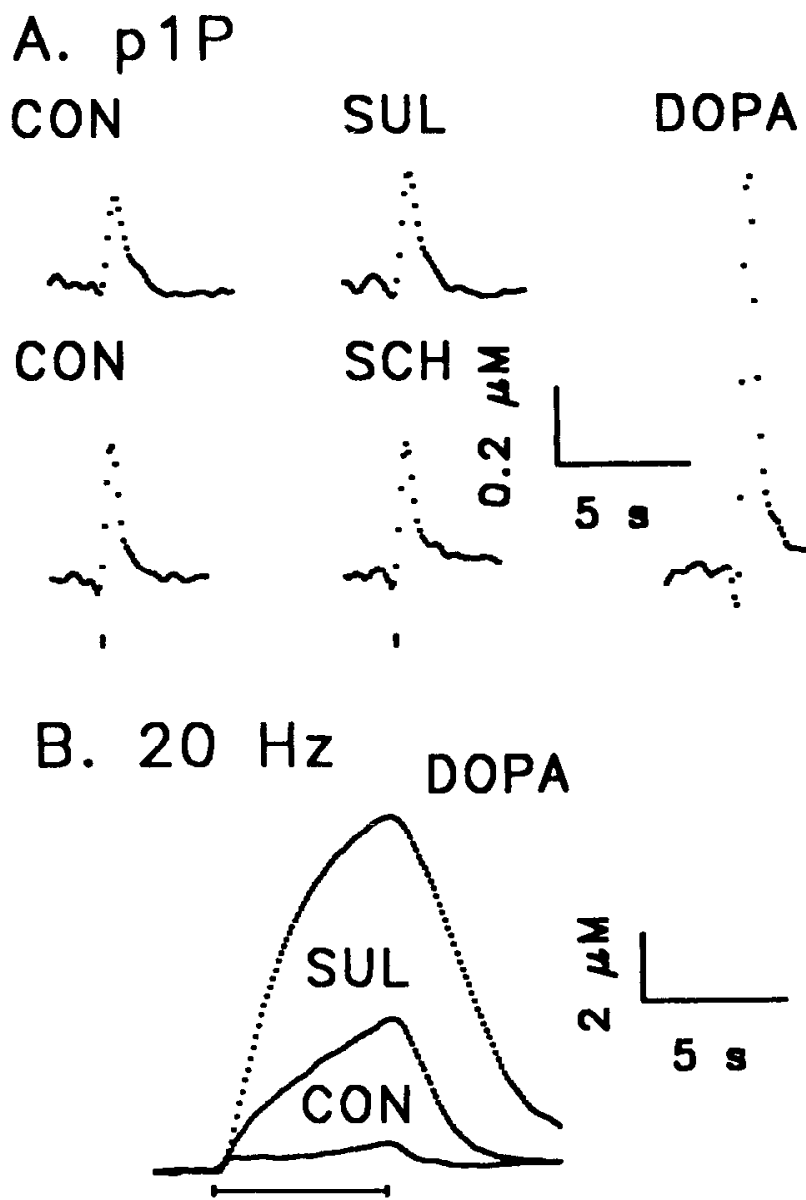

Figure 3. A, Individual curves elicited by $\mathrm{p} 1 \mathrm{P}$ stimulation before drug $(C O N)$, after sulpiride $(S U L ; 100 \mathrm{mg} / \mathrm{kg})$, or $S C H 23390(S C H ; 0.1 \mathrm{mg})$ $\mathrm{kg}$ ), and after $\mathrm{L}$-dopa (DOPA; $250 \mathrm{mg} / \mathrm{kg}$ ). Respective control curves for SUL and SCH are shown immediately before. The curve for dopa was collected in the samc location as SCH. The periphcral decarboxylase inhibitor RO $4-4062(60 \mathrm{mg} / \mathrm{kg})$ was administered $30 \mathrm{~min}$ before $\mathrm{L}-\mathrm{do}$ pa. $B$, Individual curves elicited by a $6 \mathrm{sec}$ train of $20 \mathrm{~Hz}$ stimulation in control, and after sulpiride and L-dopa. Data were collected at the same location shown in $A$ for SUL. Scans were collected every 100 msec. Curves are the average of 20 measurements for pIP and one to four measurements for $20 \mathrm{~Hz}$ stimulation.

transmission at the neuromuscular junction differ greatly in that the dopamine released into the synaptic cleft seems destined for extrasynaptic space.

\section{Temporal and spatial dopamine concentrations after release}

The central conclusion of this article, that dopamine synapses are designed for transmitter efflux, can be further evaluated based on diffusional time scales and the anatomy and neurochemistry of the striatum. First, consider the time course for dopamine efflux from the synaptic cleft following release for the case of unrestricted diffusion (Appendix 1). Based on the free solution diffusion coefficient of dopamine, the concentration at the postsynaptic membranc will reach its maximum valuc in less than $0.5 \mu \mathrm{sec}$ following a vesicular release event, and will remain at this value for approximately $2.5 \mu \mathrm{sec}$ until the material diffuses to the edge of the disk-shaped synaptic cleft (Fig. 5). The concentration will then fall as material leaves the synaptic cleft, and after $40 \mu \mathrm{sec}$, more than $96 \%$ of the material will have diffused out. The diffusion of $\mathrm{ACh}$ in the neuromuscular junc- 


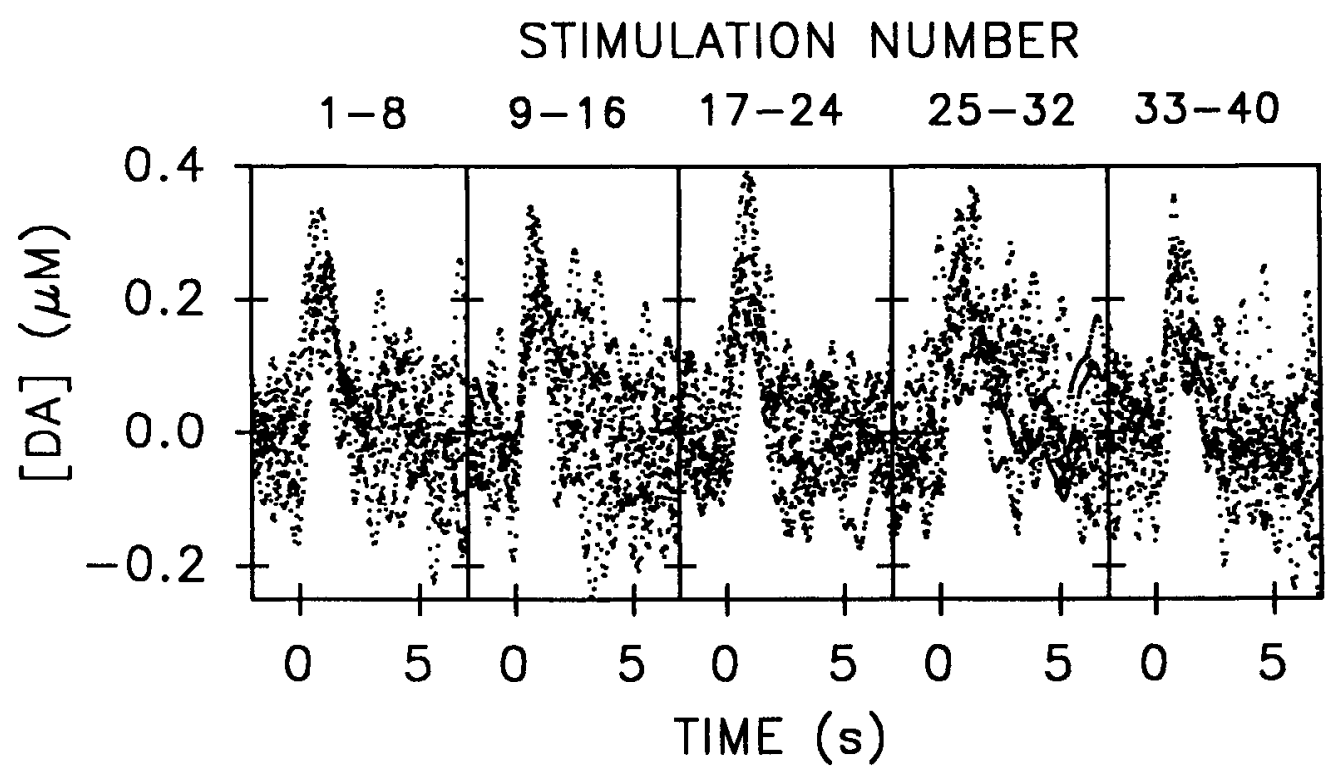

Figure 4. Unaveraged responses elicited by $1 \mathrm{P}$ stimulation in the presence of nomifensine $(25 \mathrm{mg} / \mathrm{kg})$. Each pane shows eight superimposed curves from consecutive stimulations. Scans were collected every $50 \mathrm{msec}$ and the stimulus pulse was applied at time zero. Curves were recorded in the same location at one electrode and collected at intervals of $30 \mathrm{sec}$. The unsynchronized, smaller peaks in the traces are electrical noise.

volume fraction of 0.2 (Rice and Nicholson, 1991), the number of dopamine molecules contained in a single $2 \mu \mathrm{m}$ sphere is calculated to be

$$
\begin{aligned}
& \frac{250 \times 10^{-9} \mathrm{~mol}}{\text { liter }} \times \frac{4}{3} \pi(2 \mu \mathrm{m})^{3} \times \frac{6.02 \times 10^{23} \text { molecules }}{\mathrm{mol}} \times 0.2 \\
& =1000 \text { DA molecules. }
\end{aligned}
$$

This represents the average number of dopamine molecules that escape from each synaptic cleft during a stimulus pulse. The concentration of these molecules when occupying the much smaller volume of the synaptic cleft is much greater and can be estimated by

$$
\begin{aligned}
& \frac{1000 \text { molecules DA }}{\pi(0.15 \mu \mathrm{m})^{2 *}(0.015 \mu \mathrm{m})} \\
& \quad \times \frac{1 \mathrm{~mol}}{6.02 \times 10^{23} \text { molecules }}=1.6 \mathrm{mM} \mathrm{DA} .
\end{aligned}
$$

This is a surprisingly high concentration since it greatly exceeds the affinity of dopamine for uptake transporters and receptors (Boyson et al., 1986; Dawson et al., 1986; Richfield et al., 1989; Horn, 1990). However, as shown by the diffusional calculations for dopamine efflux from the synaptic cleft, this large concentration of dopamine will exist only transiently. Similarly, high concentrations have been estimated for glutamate in the synaptic cleft of cultured hippocampal neurons following release (Clements et al., 1992). Interestingly, the concentration of this number of dopamine molecules when occupying the volume of a single dopamine vesicle (radius $=25 \mathrm{~nm}$; Pickel et al., 1981) is

$$
\frac{1000 \text { molecules DA }}{\frac{4}{3} \pi(25 \mathrm{~nm})^{3}} \times \frac{1 \mathrm{~mol}}{6.02 \times 10^{23} \text { molecules }}=25 \mathrm{~mm} \mathrm{DA} \text {. }
$$

This value is reasonable compared to other secretory vesicles (Dahlstrom and Haggendahl, 1966; Kuffler and Yoshikami, 1975).

These calculations are based on the assumption that all dopamine synapses in the sensing region of the working electrode are activated to release. To achieve this condition, we have

\section{Concentrations of dopamine in the synaptic cleft and extrasynaptic fluid}

Experimentally, it was found that a single stimulus pulse causes a maximal extracellular dopamine concentration of $250 \mathrm{nM}$. This is the average concentration in all of the dopamine synaptic "spheres" adjacent to the sensor. Accounting for an extracellular 

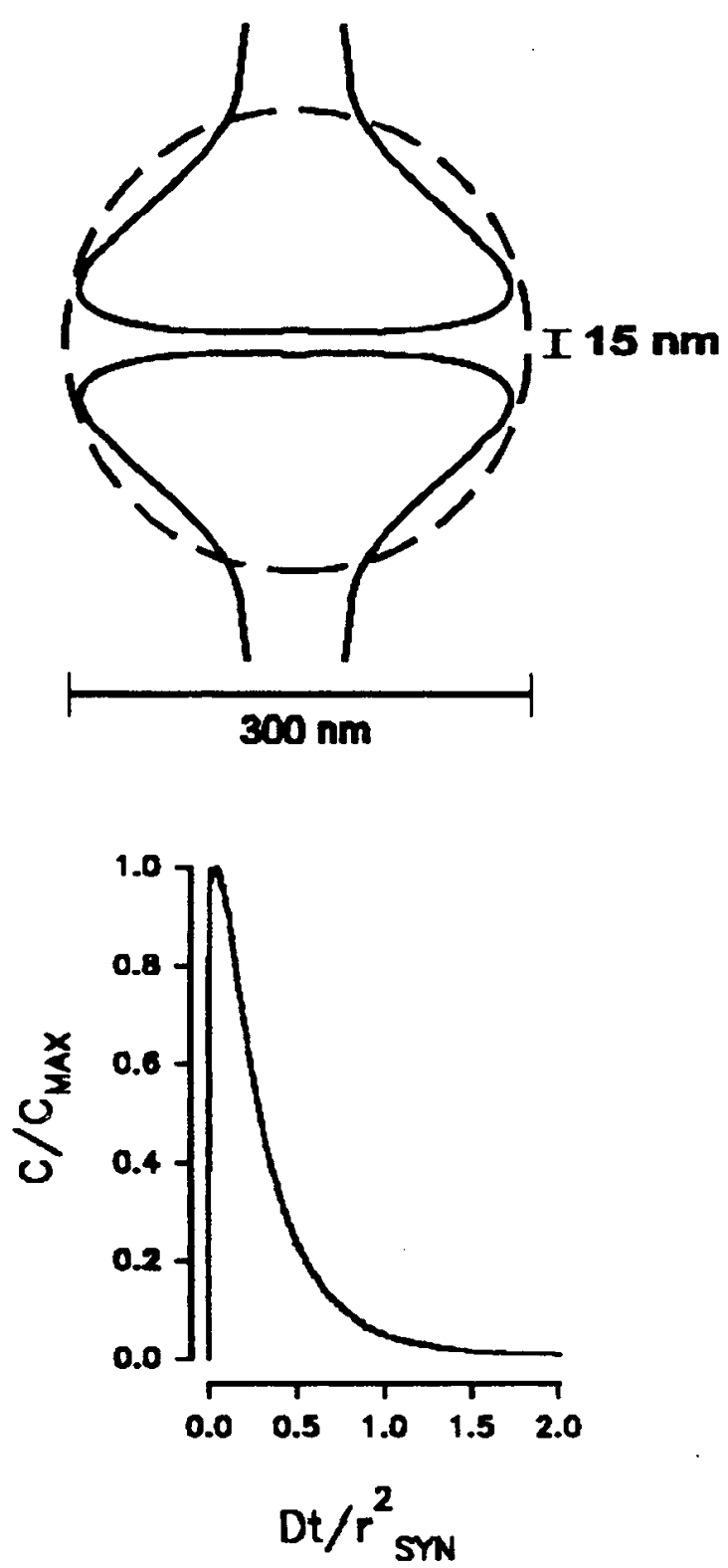

Figure 5. Geometry of the synaptic model and predicted time course of dopamine efflux from the synaptic cleft. See Appendix 1 for a description of the simulation parameters employed.

employed supramaximal stimulating currents and a large stimulating electrode (Wiedemann et al., 1992). This paradigm activates ascending dopamine fibers arising from both the substantia nigra and ventral tegmental area, which converge in the medial forebrain bundle (Garris et al., 1993). However, stimulation of sympathetic norepinephrine fibers, neurons with an extensive arborization like mesostriatal dopamine neurons, leads to failure of release at individual synapses $99 \%$ of the time (Cunnane and Stjarne, 1984). The determination of an equivalent failure rate for mesostriatal dopamine neurons is difficult because our sensors sample from an average of 30 dopamine synapses (Stamford et al., 1986). Nonetheless, we have not observed any failures of dopamine release elicited by a single stimulus pulse from the population of dopamine synapses within the sensing region of our working electrode in the nucleus accumbens (Fig. 4). The results suggest differences in the conduc-
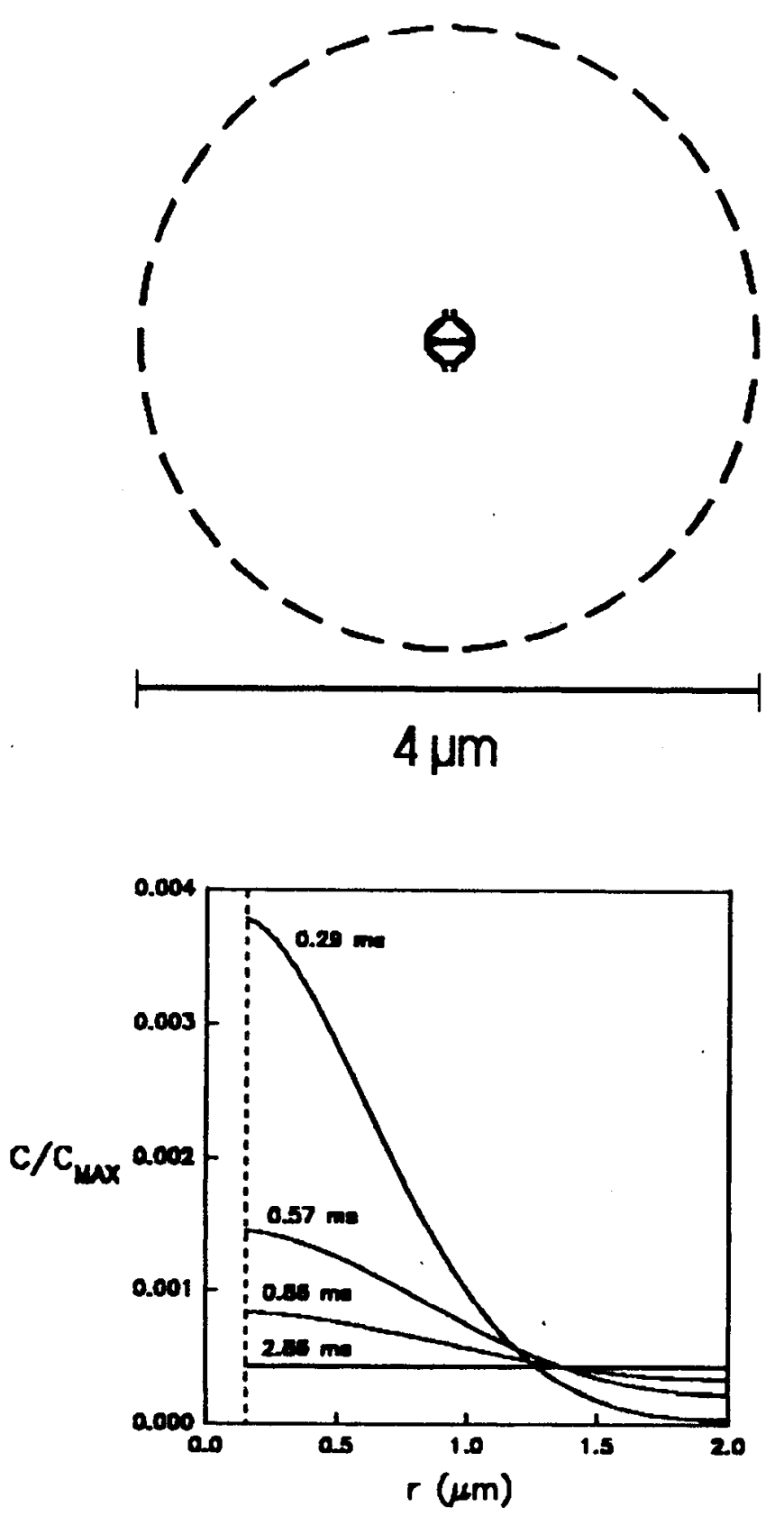

Figure 6. Geometry of the extrasynaptic model and predicted concentration profiles. See Appendix 2 for a description of the simulation parameters. The dotted line at $r=0.15 \mu \mathrm{m}$ represents boundary of the synapse. Scale relative to Figure 5 is approximately $1: 11$.

tion propertics and probability of vesicular release between central dopamine neurons and sympathetic norepinephrine neurons.

In the unstimulated animal, synapses are more likely to fire asynchronously such that further extrasynaptic diffusion and uptake by adjacent synapses will cause more rapid dilution in the extrasynaptic space than these calculations suggest. The net result is that the temporally and spatially averaged concentration of extracellular dopamine in the striatum in situ is predicted to be in the low nanomolar range (Kawagoe et al., 1992), a result that agrees with in vivo measurements by microdialysis (Parsons and Justice, 1992). Thus, depending on the temporal and spatial domain of a measurement, extracellular dopamine concentrations in the nucleus accumbens can vary over 6 orders of magnitude. 


\begin{tabular}{|c|c|c|}
\hline & $\begin{array}{l}B_{\max } \\
\text { (pmol/ } \\
\text { mg pro- } \\
\text { tein) }\end{array}$ & Reference \\
\hline \multicolumn{3}{|l|}{ Caudate nucleus } \\
\hline \multirow[t]{4}{*}{$D_{1}$ receptor } & 2.2 & Dawson et al., 1986 \\
\hline & 2.4 & Boyson et al., 1986 \\
\hline & 2.7 & Richfield et al., 1989 \\
\hline & 4.8 & Savasta et al., 1986 \\
\hline \multirow[t]{4}{*}{$\mathrm{D}_{2}$ receptor } & 0.5 & Martres et al., 1985 \\
\hline & 0.5 & Joyce and Marshall, 1987 \\
\hline & 0.8 & Boyson et al., 1986 \\
\hline & 1.1 & Richfield et al., 1989 \\
\hline \multirow[t]{8}{*}{ DA transporter } & 0.4 & Andersen, 1989 \\
\hline & 0.5 & Boja et al., 1992 \\
\hline & 2.8 & Scatton et al., 1985 \\
\hline & 5.5 & Horn, 1990 \\
\hline & 6.5 & Dubocovich and Zahniser, 1985 \\
\hline & 7.0 & Marshall et al., 1990 \\
\hline & 7.8 & Javitch et al., 1985 \\
\hline & 16.5 & Mennicken et àl., 1992 \\
\hline \multicolumn{3}{|l|}{ Nucleus accumbens } \\
\hline \multirow[t]{2}{*}{$D_{1}$ receptor } & 1.9 & Dawson et al., 1986 \\
\hline & 2.5 & Boyson ct al., 1986 \\
\hline $\mathrm{D}_{2}$ receptor & 0.7 & Boyson et al., 1986 \\
\hline \multirow[t]{2}{*}{ DA transporter } & 3.4 & Marshall et al., 1990 \\
\hline & 8.3 & Mennicken et al., 1992 \\
\hline
\end{tabular}

Comparison of dopamine efflux from synaptic cleft with uplake and receptor siles

The experimental data show that dopamine uptake and receptor sites do not affect dopamine efflux from the synaptic cleft caused by synchronized impulse flow. Several reasons could account for this observation. It could be that the majority of dopamine uptake and receptor sites are located extrasynaptically or that the kinetics of binding to these sites are slow compared to the time scale of diffusion. Alternatively, the number of dopamine molecules released by a single impulse could greatly exceed the number of interaction sites located in the synaptic cleft. Current estimates for the density of dopamine uptake sites in the rat striatum are approximately $5.9 \mathrm{pmol} / \mathrm{mg}$ protein (Table 1 ). Since the transporter density is in the nucleus accumbens is about half that in the caudate-putamen, the number of uptake sites per dopamine synapse in the former is calculated to be

$$
\begin{aligned}
& \frac{3.0 \times 10^{-12} \mathrm{~mol}}{\mathrm{mg} \text { protein }} \times \frac{1 \mathrm{mg} \text { protein }}{10 \mathrm{~mm}^{3} \text { tissue }} \times \frac{1 \mathrm{~mm}^{3} \text { tissue }}{1 \times 10^{8} \text { synapses }} \\
& \times \frac{6.02 \times 10^{23} \text { sites }}{\mathrm{mol}}=1750 \frac{\text { uptake sites }}{\text { synapse }} .
\end{aligned}
$$

The number of receptor sites per synapse can also be estimated from literature values (Table 1). The average number of $D_{1}$ receptors per synapse is

$$
\begin{aligned}
& \frac{2.75 \text { pmol }}{\text { mg protein }} \times \frac{1 \mathrm{mg} \text { protein }}{10 \mathrm{~mm}^{3} \text { tissue }} \times \frac{1 \mathrm{~mm}^{3} \text { tissue }}{1 \times 10^{8} \text { synapses }} \\
& \quad \times \frac{6.02 \times 10^{23}}{\text { mol }}=1655 \frac{\text { sites }}{\text { synapse }}
\end{aligned}
$$

\section{DOPAMINE NEUROTRANSMISSION}

CLASSICAL

PROPOSED

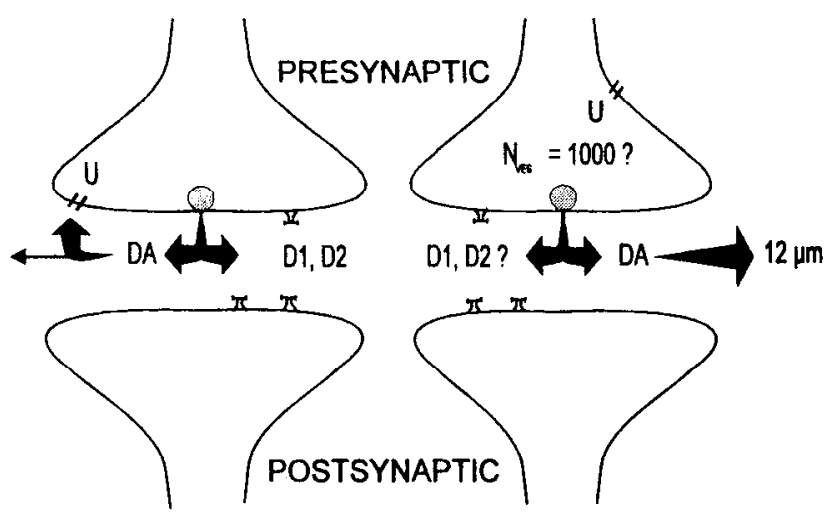

Figure 7. Schematic drawings of dopamine neurotransmission in the core of the nucleus accumbens.

Likewise, the average number of $D_{2}$ sites is calculated to be $433 /$ dopamine synapse.

An estimate of the binding rate constant of dopamine to uptake sites can be made in a manner analogous to that made for $\mathrm{AChE}$ at the neuromuscular junction (Rosenberry, 1975). For the following reaction scheme:

$$
\mathrm{DA}_{o}+U \underset{\mathrm{k}_{-1}}{\stackrel{\mathrm{k}_{1}}{\rightleftharpoons}}[\mathrm{DA}-U] \stackrel{\mathrm{k}_{2}}{\rightarrow} \mathrm{DA}_{i}+U,
$$

where $\mathrm{DA}_{\nu}$ and $\mathrm{DA}_{i}$ are extracellular and intracellular dopamine, respectively, and $U$ is the uptake carrier, $V_{\max }$ is defined as $k_{2} *[U]_{\mathrm{tot}}$, where $[U]_{\mathrm{tot}}$ is the concentration of uptake sites. For a $V_{\max }$ of $\left.3 \mu \mathrm{M} \mathrm{sec}\right)^{-1}$ and a $[U]_{\text {tot }}$ of $0.43 \mu \mathrm{M}$, the turnover rate constant, $k_{2}$, is calculated to be $7 \mathrm{sec}^{-1}$ in the nucleus accumbens. This number is similar to the reported value for the GABA uptake transporter (Mager et al., 1993) but considerably smaller than the turnover rate for AChE (Rosenberry, 1975). Since $K_{\mathrm{m}}$ is defined as $\left(k_{2}+k_{-1}\right) / k_{1}$, the lower limit for $k_{1}$ can be estimated by setting $k_{-1}=0$, which gives $k_{1}=4 \times 10^{7} \mathrm{M}^{-1}$ $\mathrm{sec}^{-1}$. This value is very large and comparable to that reported for the initial binding of ACh to AChE $\left(1.6 \times 10^{8} \mathrm{M}^{-1} \mathrm{sec}^{-1}\right.$; Rosenberry, 1975). Unfortunately, we do not have estimates of the kinetic values for dopamine binding to its receptors.

The calculations given above show that the average number of dopamine molecules released per synapse per stimulus pulse (approximately 1000 molecules) is lower than the sum of the receptor and uptake sites associated with each dopamine synapse in the nucleus accumbens. Thus, the efflux of dopamine from the synaptic cleft occurs because binding kinetics are slow or these sites are extrasynaptic. In the case of the uptake transporter, the rapid binding rate calculated above and the absence of effect of uptake inhibitors on dopamine efflux lead us to predict that a significant fraction of the uptake sites are extrasynaptic as is found in cultured fetal dopamine neurons (Cerrutti et al., 1991). Since the complete development of dopamine autoreceptor inhibition occurs in the 40-100 msec range (Mayer et al., 1988; Singer, 1988; Kennedy et al., 1992), which indicates that autoreceptors have sufficiently fast binding kinetics to buffer efflux from the synaptic cleft, the failure to alter dopamine efflux with a $\mathrm{D}_{2}$ antagonist also suggests an extrasynaptic location for dopamine autoreceptors. Indeed, recent anatomical evidence 
supports an extrasynaptic location for some $\mathrm{D}_{2}$ receptors in the rat striatum (Levey et al., 1993; Sesack et al., 1994). Speculation conccrning the location of $\mathrm{D}_{1}$ and other $\mathrm{D}_{2}$ receptor sites using our results is tenuous without kinetic binding constants.

\section{Conclusions}

The experimental results show that dopamine synapses in the nucleus accumbens of the rat brain allow efflux to the extrasynaptic region even in the limit of a single stimulus pulse. In this regard, they greatly differ from the classical model for chemical communication in the CNS, the neuromuscular junction. Thus, we propose that the view of dopaminergic neurotransmission should be modified in the manner suggested by Figure 7 . Although the dopamine uptake transporter is present in the vicinity of the synaptic region at a relatively high density and has rapid binding kinetics, it does not play the analogous role to AChE, prevention of transmitter efflux from the synaptic cleft. Rather, it appears that the transporter is extrasynaptic, and its rolc in dopamine ncurotransmission is regulation of cxtrasynaptic dopamine levels and the distance that dopamine can diffuse from the synapse. Another important difference with the neuromuscular junction is that the turnover rate for the dopamine transporter is much slower than that for the esterase. Thus, even if dopamine uptake sites are located within the synaptic cleft, their functional role is still to regulate extrasynaptic dopamine levels.

The physiological consequences of these dynamic dopamine concentration gradients rest on the interaction of released dopamine with receptor sites. This seems quite likely, since the evoked dopamine concentration transients in the extracellular fluid are near the reported $K_{d}$ values of dopamine receptors (Richfield et al., 1989). These extrasynaptic dopamine concentrations are rapidly lowered by uptake, but there is still sufficient time for dopamine to diffuse more than $10 \mu \mathrm{m}$ within one halflife from its release site (Garris and Wightman, 1994). Within this volume, freely diffusing dopamine can interact with more than 200 other dopamine synapses. A recent anatomical study in the rat indicates that the majority of striatal $D_{1}$ and $D_{2}$ receptors are located on dendrites shafts and spine heads of medium spiny neurons (Levey et al., 1993) while dopamine neurons typically synapse on the neck of dendritic spines (Pickel et al., 1981; Gerfen, 1988; Groves et al., 1994). Thus, while our data do not exclude a synaptic mode for dopamine neurotransmission, extrasynaptic communication by dopamine in the striatum has a high likelihood based on both experimental and calculated results.

Instead of being a single focal point for chemical communication, then, the dopamine synapse acts on cells within a perimeter specified by dopamine uptake and release. Real meaning can now be given to the evoked responses of extracellular dopamine concentration measured by fast-scan voltammetry in vivo since the time courses are well described in terms of these two factors (Wightman et al., 1988; Wightman and Zimmerman, 1990). Furthermore, differences in dopamine release and uptake have been demonstrated in the telencephalon (Garris and Wightman, 1994) and regional variations in the temporal and spatial dynamics of extrasynaptic dopamine communication are anticipated. For example, dopamine uptake on a per synapse basis is 10-fold less in the basolateral amygdaloid nucleus compared to the striatum, which indicates that the area over which a single dopamine synapse influences is much larger in the former and illustrates how dopamine neurotransmission is region- ally modified. A similar process may occur in Parkinson's disease (Zigmond et al., 1990). When uptake is compromised due to the progressive loss of dopamine neurons, the longer-range diffusion of dopamine will be facilitated.

While the conclusions of this article are based on measurements of dopamine in the nucleus accumbens and directly relate to dopamine neurotransmission, they may be extended to chemical communication for other neurotransmitters in the brain as well. The proposed view of neurotransmission would apply to all neuronal systems that exhibit an equivalent synaptic architecture and regulation similar to the dopamine synapse and different from the neuromuscular junction. Certainly monoamines fit this description. Unfortunately, comparable information for the dynamic regulation of extracellular concentration gradients is not available for other neurotransmitters in the CNS and this hypothesis remains to be tested. Nonetheless, the results suggest that all neuronal connections of the brain are not "hardwired" and that chemical communication is not always reduced to the functional limit of a single synapse.

\section{Appendix 1}

To describe diffusional transport within the synaptic cleft in the first moments after an action potential arrives, the dopamine synapse was modeled with a random-walk algorithm. The algorithm employed is based on a previously described simulation (Schroeder et al., 1992). The assumptions of the model are that the synaptic cleft is represented by the cylindrical volume element between two parallel, circular plates; release is instantaneous, and occurs at the center of one (presynaptic) plate; and diffusion is the only mode of mass transport. The two plates are treated as reflecting boundaries, and the average concentration of released material in the volume elements adjacent to the opposite (postsynaptic) plate was calculated after every time step. Particles were allowed to diffuse back into the synaptic cleft after they had exitcd into the extrasynaptic spacc. A graphical representation of the dopamine synapse is shown in Figure 5. Because we wish to describe the maximum efflux of dopamine from the synaptic cleft, receptor and uptake interactions are not considered.

The results of the simulation are shown in Figure 5 in terms of the dimensionless parameters $C / C_{\max }$ and $D t / r_{\text {syn }}{ }^{2}$, where $C$ is the concentration, $C_{\max }$ is the maximum concentration, $D$ is the diffusion coefficient, $t$ is time, and $r_{\text {syn }}$ is the radius of the synaptic cleft. The falling portion of the curve is similar to that obtained by Eccles and Jaeger (1958). The rising portion of the curve is dependent on the dimensionless parameter $w / r_{\text {syn }}$, where $w$ is the width of the synaptic cleft, and employed a value of $0.1\left(w=15 \mathrm{~nm}, r_{\text {syn }}=150 \mathrm{~nm}\right)$ for the present conditions. For smaller values of $w / r_{\text {syn }}$, the plateau at $C_{\max }$ will have a longer duration, whereas for larger values, the plateau will eventually disappear. The actual time required for material to exit the synapse is directly proportional to the magnitude of the diffusion coefficient. A similar time course can also be calculated with the model developed by Eccles and Jaeger (1958). The present model accounts for the dispersal of the released contents in the synaptic cleft and the effects of diffusion in the extrasynaptic space, which leads to a slightly longer time course.

\section{Appendix 2}

After dopamine exits the synaptic cleft, it is free to diffuse throughout the extrasynaptic space. The condition we wish to model is release during stimulation of the ascending fibers in 
the medial forebrain bundle. It will be assumed that every dopamine synapse releases a finite amount of transmitter in response to each stimulus pulse. Because every dopamine synapse is completely surrounded by other dopamine synapses undergoing the identical processes, it is only necessary to simulate the events at a single synapse and in the space immediately surrounding that synapse, which we term the "sphere of influence." This situation was modeled by a finite difference method with the following assumptions. The geometry was that of two concentric spheres. The radius of the inner sphere was set to 150 $\mathrm{nm}$, the average radius of a dopamine synapse, and the radius of the outer sphere was set to $2 \mu \mathrm{m}$ (Fig. 6). It was found that varying the radius of the inner sphere had a negligible effect on the calculated results. Escape from the synaptic cleft was assumed to be instantaneous (see Appendix 1), and both spherical boundaries were treated as diffusional barriers. Mass transport throughout the sphere of influence was by diffusion, and assumed a diffusion coefficient equal to the solution value. Concentration profiles within the sphere of influence at various times after release are illustrated in Figure 6 . The concentrations have been normalized to the initial concentration, which was taken to be the maximum concentration observed in the synaptic cleft. At the time that equilibrium is achieved throughout the sphere of influence ( $3 \mathrm{msec}$ ), the concentration is uniform throughout the extrasynaptic space.

The concentration in each sphere of influence at the instant equilibrium is attained can be determined by a simple dilution calculation. The volume of the synaptic cleft is $\pi\left(150 \times 10^{-7}\right.$ $\mathrm{cm})^{2}\left(15 \times 10^{-7} \mathrm{~cm}\right)=1.06 \times 10^{-18}$ liter, whereas the volume of the sphere of influence is $(4 / 3) \pi\left(2 \times 10^{-4} \mathrm{~cm}\right)^{3}=3.35 \times$ $10^{-14}$ liter. Accounting for that fraction of the extracellular space that is available for diffusion $(0.2)$, the concentration in the sphere of influence at equilibrium will be 6300 times less than the maximum concentration that had been attained inside the synaptic cleft.

\section{References}

Adams RN (1990) In vivo electrochemical measurements in the CNS. Prog Neurobiol 35:297-311.

Andersen PH (1989) The dopamine uptake inhibitor GBR 12909: selectivity and molecular mechanism of action. Eur J Pharmacol 166 : 493-504.

Armstrong DL, Lester HA (1979) The kinetics of tubocurarine action and restricted diffusion within the synaptic cleft. J Physiol (Lond) 294:365-386.

Bannon MJ, Roth RH (1983) Pharmacology of mesocortical dopamine neurons. Pharmacol Rev 35:53-68.

Bartol TM, Land BR, Salpeter EL, Salpeter MM (1991) Monte Carlo simulation of miniature endplate current generation in the vertebrate neuromuscular junction. Biophys J 59:1290-1307.

Baur JE, Kristensen EW, May LJ, Wiedemann DJ, Wightman RM (1988) Fast-scan voltammetry of biogenic amines. Anal Chem 60: 1268-1272.

Boja JW, Mitchell WM, Patel A, Kopajtic TA, Carroll FI, Lewin AH, Abraham P, Kuhar MJ (1992) High-affinity binding of [125I]RTI55 to dopamine and serotonin transporters in rat brain. Synapse 12: 27-36.

Boyson SJ, McGonigle P, Molinoff PB (1986) Quantitative autoradiographic localization of the $D_{1}$ and $D_{2}$ subtypes of dopamine receptors in rat brain. $J$ Neurosci 6:3177-3188.

Cerruti C, Drian MJ, Kamenka JM, Privat A (1991) Localization of dopamine carriers by BTCP, a dopamine uptake inhibitor, on nigral cells cultured in vitro. Brain Res 555:51-57.

Clements JD, Lester RA, Tong JG, Jahr CE, Westbrook GL (1992) The time course of glutamate in the synaptic cleft. Science 258:14981501 .
Cooper JC, Bloom FE, Roth RH (1991) The biochemical basis of neuropharmacology. New York: Oxford UP.

Cunnane TC, Stjarne L (1984) Transmitter secretion from individual varicosities of guinea-pig and mouse vas deferens: highly intermittent and monoquantal. Neuroscience 13:1-20.

Dahlstrom A, Haggendal J (1966) Studies on the transport and lifespan of amine storage granules in a peripheral adrenergic system. Acta Physiol Scand 67:278-288.

Dawson TM, Gehlert DR, McCabe RT, Barnett A, Wamsley JK (1986) D-1 dopamine receptors in the rat brain: a quantitative autoradiographic analysis. J Neurosci 6:2352-2365.

Descarries L, Lemay B, Doucet $G$, Rerger B (1987) Regional and laminar density of the dopamine innervation in adult rat cerebral cortex. Neuroscience 21:807-824.

Doucet G, Descarries L, Garcia L (1986) Quantification of the dopamine innervation in adult rat neostriatum. Neuroscience 19:427445.

Dubocovich ML, Zahniser NR (1985) Binding characteristics of the dopamine uptake inhibitor $\left[{ }^{3} \mathrm{H}\right]$ nomifensine to striatal membranes. Biochem Pharmacol 34:1137-1144.

Eccles JC, Jaeger JC (1958) The relationship between the mode of operation and the dimensions of the junctional regions at synapses and motor end-organs. Proc R Soc Lond [Biol] 148:38-56.

Ewing AG, Strein TG, Lau YY (1992) Analytical chemistry in microenvironments: single nerve cells. Acc Chem Res 25:440-447.

Freund TF, Powell JF, Smith AD (1984) Tyrosine hydroxylase-immunoreactive boutons in synaptic contact with identified striatonigral neurons, with particular reference to dendritic spines. Neuroscience 13:1189-1215.

Fuxe K, Agnati LF (1991) Two principal modes of electrochemical communication in the brain: volume versus wiring transmission. In: Volume transmission in the brain: novel mechanisms for neural transmission (Fuxe K, Agnati LF, eds), pp 1-9. New York: Raven.

Garris PA, Wightman RM (1994) Different kinetics govern dopaminergic transmission in the amygdala, prefrontal cortex, and striatum: an in vivo voltammetric study. J Neurosci 14:442-450.

Garris PA, Collins LB, Jones SR, Wightman RM (1993) Evoked extracellular dopamine in vivo in the medial prefrontal cortex. J Neurochem 61:637-647.

Gerfen CR (1988) Synaptic organization of the striatum. J Electron Microsc Tech 10:265-281.

Giros B, Caron MG (1993) Molecular characterization of the dopamine transporter. Trends Pharmacol Sci 14:43-49.

Glowinski J, Tassin JP, Thierry AM (1984) The mesocortico-prefrontal dopaminergic neurons. Trends Neurosci 7:414-418.

Gonon FG, Suaud-Chagny MF, Mermet CC, Buda M (1991) Relation between impulse flow and extracellular catecholamine levels as studied by in vivo electrochemistry in CNS. In: Volume transmission in the brain: novel mechanisms for neural transmission (Fuxe K, Agnati LF, eds), pp 337-350. New York: Raven.

Groves PM, Linder JC, Young SJ (1994) 5-Hydroxydopamine-labeled dopaminergic axons: three-dimensional reconstructions of axons, synapses and postsynaptic targets in rat neostriatum. Neuroscience 58:593-604.

Horn AS (1990) Dopamine uptake: a review of progress in the last decade. Prog Neurobiol 34:387-400.

Javitch JA, Strittmatter SM, Snyder SH (1985) Differential visualization of dopamine and norepinephrine uptake sites in rat brain using $\left[{ }^{3} \mathrm{H}\right]$ mazindol autoradiography. J Neurosci 5:1513-1521.

Johnson SW, Hoffer BJ, Freedman R (1986) Investigation of the failure of parenterally administered haloperidol to antagonize dopamine released from micropipettes in the caudate. J Neurosci 6:572-580.

Joyce JN, Marshall JF (1987) ' Quantitative autoradiography of dopamine $\mathrm{D}_{2}$ sites in rat caudate-putamen: localization to intrinsic neurons and not to neocortical afferents. Neuroscience 20:773-795.

Katz B, Miledi R (1973) The binding of acetylcholine to receptors and its removal from the synaptic cleft. J Physiol (Lond) 231:549-573.

Kawagoe KT, Garris PA, Wightman RM (1992) Regulation of transient dopamine concentration gradients in the micro-environment surrounding nerve terminals in the rat striatum. Neuroscience 51:5564.

Kawagoe KT, Zimmerman JB, Wightman RM (1993) Principles of voltammetry and microelectrode surface states. J Neurosci Methods 48:225-240.

Kennedy RT, Jones SR, Wightman RM (1992) Dynamic observation 
of dopamine autoreceptor effects in rat striatal slices. J Neurochem 59:449-455.

Kilts CD, Anderson CM, Ely TD, Mailman RB (1988) The biochemistry and pharmacology of dopamine neurons. Ann NY Acad Sci 537: 173-187.

Kuffler SW, Yoshikami D (1975) The number of transmitter molecules in a quantum: an estimate from iontophoretic application of acetylcholine at the neuromuscular synapse. J Physiol (Lond) 251:265.

Kuhr WG, Ewing AG, Caudill WL, Wightman RM (1984) Monitoring the stimulated release of dopamine with in vivo voltammetry. I. Characterization of the response observed in the caudate nucleus of the rat. J Neurochem 43:560-569.

Land BR, Salpeter EE, Salpeter MM (1980) Acetylcholine receptor site density affects the rising phase of miniature endplate currents. Proc Natl Acad Sci USA 77:3736-3740.

Land BR, Salpeter EE, Salpeter MM (1981) Kinetic parameters for acetylcholine interaction in intact neuromuscular junction. Proc Natl Acad Sci USA 78:7200-7204.

Land BR, Harris WV, Salpeter EE, Salpeter MM (1984) Diffusion and binding constants for acetylcholine derived from the falling phase of miniature cndplate currents. Proc Natl Acad Sci USA 81:1594-1598.

Le Moal M, Simon H (1991) Mesocorticolimbic dopamine network: functional and regulatory roles. Physiol Rev 71:155-234.

Levey AI, Hersch SM, Rye DB, Sunahara RK, Niznik HB, Kitt CA, Price DL, Maggio R, Brann MR, Ciliax BJ (1993) Localization of $D_{1}$ and $D_{2}$ dopamine receptors with subtype-specific antibodies. Proc Natl Acad Sci USA 90:8861-8865.

Limberger N, Trout SJ, Kruk ZL, Starke K (1991) "Real time" measurement of endogenous dopamine release during short trains of pulses in slices of rat neostriatum and nucleus accumbens: role of autoinhibition. Naunyn Schmiedebergs Arch Pharmacol 344:623-629.

Mager S, Naeve J, Quick M, Labarca C, Davidson N, Lester HA (1993) Steady states, charge movements, and rates for a cloned GABA transporter expressed in Xenopus oocytes. Neuron 10:177-188.

Magleby KL, Terrar DA (1975) Factors affecting the time course of decay of end-plate currents: a possible cooperative action of acetylcholine on receptors at the frog neuromuscular junction. J Physiol (Lond) 244:467-495.

Marshall JF, O'Dell SJ, Navarrete R, Rosenstein AJ (1990) Dopamine high-affinity transport site topography in rat brain: major differences between dorsal and ventral striatum. Neuroscience 37:11-21.

Martres MP, Bouthenet ML, Sales N, Sokoloff P, Schwartz JC (1985) Widespread distribution of brain dopamine receptors evidenced with [25I]iodosulpride, a highly selective ligand. Science 228:752-755.

May LJ, Kuhr WG, Wightman RM (1988) Differentiation of dopamine overflow and uptake processes in the extracellular fluid of the rat caudate nucleus with fast-scan in vivo voltammetry. J Neurochem 51:1060-1069.

Mayer A, Limberger N, Starke K (1988) Transmitter release patterns of noradrenergic, dopaminergic and cholinergic axons in rabbit brain slices during short pulse trains, and the operation of presynaptic autoreceptors. Naunyn Schmiedebergs Arch Pharmacol 338:632-643.

Mennicken F, Savasta M, Peretti-Renucci R, Feuerstein X (1992) Autoradiographic localization of dopamine uptake sites in the rat brain with ${ }^{3} \mathrm{H}-\mathrm{GBR}$ 12935. J Neural Transm 87:1-14.

Michael AC, Justice JB Jr, Neill DB (1985) In vivo voltammetric determination of the kinetics of dopamine metabolism in the rat. Neurosci Lett 56:365-369.

Millar J, Stamford JA, Kruk ZL, Wightman RM (1985) Electrochemical, pharmacological and electrophysiological evidence of rapid dopamine release and removal in the rat caudate nucleus following electrical stimulation of the medial forebrain bundle. Eur J Pharmacol 109:341-348.

Near JA, Bigelow JC, Wightman RM (1988) Comparison of uptake of dopamine in rat striatal chopped tissue and synaptosomes. J Pharmacol Exp Ther 245:921-927.

Palij P, Bull DR, Sheehan MJ, Millar J, Stamford J, Kruk ZL, Humphrey PA (1990) Presynaptic regulation of dopamine release in corpus striatum monitored in vitro in real time by fast cyclic voltammetry. Brain Res 509:172-174.
Parsons LH, Justice JB (1992) Extracellular concentration and in vivo recovery of dopamine in the nucleus accumbens using microdialysis. J Neurochem 58:212-218.

Paxinos G, Watson C (1986) The rat brain in stereotaxic coordinates. New York: Academic.

Pickel VM, Beckley SC, Joh TK, Reis BJ (1981) Ultrastructural and immunocytochemical localization of tyrosine hydroxylase in the neostriatum. Brain Res 225:373-385.

Press WH, Flannery BP, Teukolsky SA, Fetterling WT (1989) Numerical recipes in pascal. Cambridge: Cambridge UP.

Rice ME, Nicholson C (1991) Diffusion characteristics and extracellular volume fraction during normoxia and hypoxia in slices of rat neostriatum. J Neurophysiol 65:264-272.

Richfield EK, Penney JB, Young AB (1989) Anatomical and affinity state comparisons between dopamine $D_{1}$ and $D_{2}$ receptors in the rat. central nervous system. Neuroscience 30:767-777.

Rosenberry T (1975) Acetylcholinesterase. Adv Enzymol 43:103-218.

Savasta M, Dubois A, Scatton B (1986) Autoradiographic localization of $\mathrm{D}_{1}$ dopamine receptors in the rat brain with $\left[{ }^{3} \mathrm{H}\right] \mathrm{SCH} 23390$. Brain Res 375:291-301.

Scatton B, Dubois A, Dubocovich ML, Zahniser NR, Fage D (1985) Quantitative autoradiography of ${ }^{3} \mathrm{H}$-nomifensine binding sites in rat brain. Life Sci 36:815-822.

Schenk JO, Bunney BS (1987) Quantitative interpretations of in vivo chronoamperometry. In: Voltammetry in the neurosciences (Justice JB, ed), pp 139-160. Clifton, NJ: Humana.

Schroeder TJ, Jankowski JA, Kawagoe KT, Wightman RM, Lefrou C, Amatore C (1992) Analysis of diffusional broadening of vesicular packets of catecholamine released from biological cells during exocytosis. Anal Chem 64:3077-3083.

Sesack SR, Aoki C, Pickel VM (1994) Ultrastructural localization of $\mathrm{D}_{2}$ receptor-like immunoreactivity in midbrain dopamine neurons and their striatal targets. J Neurosci 14:88-106.

Singer EA (1988) Transmitter release from brain slices elicited by single pulses: a powerful method to study presynaptic mechanisms. Trends Neurosci 9:274-276.

Stamford JA, Kruk ZL, Millar J (1986) Sub-second striatal dopamine release measured by in vivo voltammetry. Brain Res 381:351-355.

Starke K, Gothert M, Kilbinger H (1989) Modulation of neurotransmitter release by presynaptic autoreceptors. Physiol Rev 69:864-989.

Valenta B, Drobny H, Singer EA (1988) Presynaptic autoinhibition of central noradrenaline release in vitro: operational characteristics and effects of drugs acting at alpha- 2 adrenoceptors in the presence of uptake inhibition. J Pharmacol Exp Ther 245:944-949.

Voorn P, Jorritsma-Byham B, van Dijk C, Buijs RM (1986) The dopaminergic innervation of the ventral striatum in the rat: a lightand electron-microscopical study with antibodies against dopamine. J Comp Neurol 251:84-99.

Wathey JC, Nass MM, Lester HA (1979) Numerical reconstruction of the quantal event at nicotinic synapses. Biophys J 27:145-164.

Wiedemann DJ, Kawagoe KT, Kennedy RT, Ciolkowski EL, Wightman RM (1991) Strategies for low detection limit measurements with cyclic voltammetry. Anal Chem 63:2965-2970.

Wiedemann DJ, Garris PD, Near JA, Wightman RM (1992) Effect of chronic haloperidol treatment on stimulated synaptic overflow of dopamine in the rat striatum. J Pharmacol Exp Ther 261:574-579.

Wightman RM, Zimmerman JB (1990) Control of dopamine extracellular concentration in rat striatum by impulse flow and uptake. Brain Res Rev 15:135-144.

Wightman RM, Amatore C, Engstrom RC, Hale PD, Kristensen EW, Kuhr WG, May LJ (1988) Real-time characterization of dopamine overflow and uptake in the rat striatum. Neuroscience 25:513-523.

Williams GV, Millar J (1990) Concentration-dependent actions of stimulated dopamine release on neuronal activity in rat striatum. Neuroscience 39:1-16.

Williams GV, Millar J (1991) Differential actions of endogenous and iontophoretic dopamine in rat striatum. Eur J Neurosci 2:658-661.

Zigmond MJ, Abercrombie ED, Berger TW, Grace AA, Stricker EM (1990) Compensations after lesions of central dopaminergic neurons: some clinical and basic implications. Trends Neurosci 13:290-295. 